\title{
'How people read and write and they don't even notice': Everyday lives and literacies on a Midlands council estate
}

\begin{abstract}
This article presents data from a British Academy funded study of the everyday literacy practices of three families living on a predominantly white working class council housing estate on the edge of a Midlands city. The study explored, as one participant succinctly put it, 'how people read and write and they don't even notice'. This alludes to the ways in which everyday practices may not be recognised as part of a dominant model of literacy. The study considered too the ways in which these literacy practices are part of a wider policy context that also fails to notice the impact of austerity politics on everyday lives. An emphasis on quantitative measures of disadvantage and public discourse which vilifies those facing economic challenge can overshadow the resilience and resourcefulness of individuals and families in making meaning from their experiences. Drawing together consideration of everyday lives and the everyday literacies which are part of them, this article explores the impact of the current policy context on access to both economic and cultural resources, showing how literacy, as part of this context, should be recognised as a powerful means not only of constricting lives, but also of constructing them.
\end{abstract}

This article draws from a small-scale ethnographic study of everyday literacy practices. Funded by a British Academy Small Research Grant ${ }^{1}$, the project followed participants from three families who live on a predominantly white working class council housing estate on the edge of a Midlands city, exploring, as one participant succinctly put it, 'how people read and write and they don't even notice'. This observation of the project's themes captures how the participant felt that the literacies we were discussing were not part of dominant understandings of what it means to read and write. It also signals a key message about the everyday lives of the families with whom I worked.

The community at the heart of the study, like others across the United Kingdom and further afield, is often defined according to deficit models based on quantitative measures of disadvantage. I outline in this article the ways in which the everyday lives of those living in such communities are presented in policy discourse, including the impact on participant families' access to economic resources when such discourses fail to 'notice' significant realities. As a cultural resource, discourse around literacy within such communities also leads to reductive models that fail to 'notice' the resourcefulness, creativity and resilience evident in everyday practices. This compounds the challenge facing individuals and families. As Fraser (1995, p. 69) has pointed out, 'economic disadvantage and cultural disrespect are currently entwined and support one another'. For Fraser, social justice demands both redistribution and recognition. The injustices of unequal distribution of resources are prominent in the growing understanding of the impact of austerity politics on everyday lives. This article explores the importance of the recognition of everyday literacies, as established in work such as that of Barton and Hamilton (1998), in not only offering an insight into the impact of the current social policy context, but also as part of a continued challenge to the threat to social justice posed by austerity politics.

\section{Recognition of everyday lives and literacies}

In this article, everyday literacy practices are taken as a lens to explore a social, economic and political context as it affects one community. As such, a view of literacy is presented which reflects the perspective of Brandt and Clinton (2002) that, as well as being reflective of immediate contexts, the local is also a site for the negotiation of the global:

\footnotetext{
${ }^{1}$ New Literacies and Cross-generational learning on a Midlands Council Estate, Small Research Grant number 113219
} 
Not only can one look to local contexts to understand local literacy, but one can also look to local literacy practices to understand key forces that organise local life (Brandt and Clinton, 2002, p. 343).

Residents of the estate have been particularly affected by a 'Perfect Storm' of policy change implemented by the Conservative-Liberal Democrat coalition government of the UK (Haddad, 2012, p.2). A tenacious discourse of undeservedness has long existed within neoliberal politics (see, for example, Taylor, 1996; Sennett, 2003). This was echoed by George Osborne, the Chancellor of the Exchequer, in a call for an end to the 'unfairness of the "something-for-nothing culture"' within the UK welfare system (Hansard, 2013). Such a discourse is part of what Taylor describes as the official text of poverty, which, she argues, critically affects the minds and imagination of the public (Taylor, 1996). In isolating a group of people based on their economic circumstances, a policy context has been created which vilifies those in need, ignoring, for example, the fact that amongst those hardest hit by austerity measures are working people finding it difficult to make ends meet in low paid employment (Class, 2013).

One of the policies which has gained a great deal of attention in the UK is the underoccupation penalty, dubbed in popular discourse as 'the bedroom tax', a policy which has had a significant impact on the life of a participant in this study, as will be shown. The policy is part of the government's stated aim of 'creating a fairer approach to Housing Benefit to bring stability to the market and improve incentives to work' (Department for Work and Pensions, 2013). As of April $1^{\text {st }}, 2013$, those deemed to be 'under-occupying' their homes saw their housing benefit reduced by up to $25 \%$, despite a lack of smaller homes for them to move into.

This is the immediate context of the lives of the families with whom I have worked on this study of everyday literacies. These families, like many others across neoliberal regimes worldwide, are part of a society where they are not amongst the few 'singled out for recognition' (Sennett, 2003, p. 3). This lack of recognition is born of a lack of what Sennett describes as 'respect'; this means individuals are 'not seen as a full human being whose presence matters'. The work of Nancy Fraser (1995) on social justice also emphasises the need for a 'critical theory of recognition' (p.69) alongside socioeconomic 'redistribution'. According to Fraser (p. 73):

economic injustice and cultural injustice are usually interimbricated so as to reinforce one another dialectically. Cultural norms that are unfairly biased against some are institutionalised in the state and the economy; meanwhile, economic disadvantage impedes equal participation in the making of culture, in public spheres and in everyday life.

Social injustice for Fraser is not only constituted by economic marginalisation and deprivation, but also through disrespect. This includes 'being routinely maligned or disparaged in stereotypic public cultural representations', as is evident in the discourse outlined above. Disrespect also involves nonrecognition: 'being rendered invisible via the authoritative representational, communicative, and interpretative practices of one's culture' (Fraser, 1995: 71). Dominant models of literacy can be seen to contribute to nonrecognition. Across neoliberal regimes worldwide, a discourse of marketisation has dominated education policy in recent decades, and government monitoring of the teaching of literacy in schools and in adult education has meant that literacy can often be characterised in these institutions by a narrowed, instrumental notion of its role and purpose (see, for example, Comber, 2012; Hamilton, 2012). For participants in this study, this view of what it means to read and write is one which influences the ways in which everyday life is experienced, often having a direct impact on access to resources, both cultural and economic. 
Alongside engagements with text controlled by dominant forces, there were examples in the study of communicative resources being used as part of creative responses to often challenging circumstances. Such practices reflect those observed in key studies of literacy within one community, which present literacy as a plural, social and locally constructed practice (e.g. Heath, 1983; Street, 1984; Barton and Hamilton, 1998). In its exploration of the role of literacy practices as part of everyday lives, this study is grounded in such an approach to literacy.

Drawing as I do on perspectives which understand literacy as socially constructed, my approach to researching everyday literacies could not be adequately accounted for by a model which isolates practice from its wider context. The place of such practices within what we understand as the 'everyday' therefore demands brief attention here. The relationship between the everyday and dominant social structures has been explored in various ways. De Certeau (1984), to give a prominent example, sees the everyday as a site for resistant practice which often occurs through 'the cracks' in proprietary power. Bourdieu's habitus (Bourdieu, 1997), another significant concept in the study of everyday life, refers to practice which is embedded in internalised established structures, and it has been seen as suggestive of normativity and submission. As Pink (2012) argues, however, to characterise everyday practice according to a binary of resistance or normativity is to limit our understanding of its complexity. The approach I have taken in this research is to view the everyday, as Pink does, as 'where we make our worlds and where our worlds make us' (p. 5).

There are epistemological links between this view of the everyday and a notion of literacy as part of cultural system which can both constrict and construct lives. This suggests that literacy is an apt lens through which to view the impact of policy on individuals, families and communities. As is seen in the examples shared below, dominant models of literacy are a significant part of the shaping of participants' lives in the current policy context. However, participants also demonstrated how everyday responses to these dominant forces can challenge an instrumental model of literacy based on deficit. These practices show families working together in ways which are inventive and intuitive, playful and fluid, moving across boundaries between generations and modalities, formal and informal spaces, across time and space and between printbased, digital and artifactual literacies. Recognition of such a view of literacy is an important part of understanding the impact of the current policy context on everyday lives and of challenging discourses that threaten social justice.

\section{Researching everyday lives and literacies: methodological approach}

The complexity of everyday life and its irreducibility is a theme which informed the methodology of this study. The research was conducted in a community with which I was already familiar as a result of working on a previous study, which tracked the impact of a community theatre project which took place over two years between 2008-2010 (Hall and Thomson, 2010; Jones et al, 2013). Over the course of the previous study, I became interested in the ways in which families were making use of a range of literacy practices in order to negotiate and share their everyday experiences. These were practices of which I was on the periphery, however. The current study allowed me to return to some of the same families in order to explore in more depth the ways in which everyday practices around text formed part of a response to the particular challenges faced within this community at a time of acute social policy churn. The study focuses on three families, representing the experience of four generations of participants. In two cases, both of which are presented here, these were families with whom I had built relationships whilst working on the previous study.

My research design included interviews and participant observation in homes, at school and in community groups. However, in trying to gain an understanding of the impact of 
a much wider context on local lives, my approach involved renegotiation of appropriate research tools through which participants could more effectively share their responses to shifting realities. This included the use of video, informed by Pink (2007), 'using the camera as a tool through which to explore informants' experiences of and engagements with the environment' (p. 245). Data generated from this approach is presented below in the story of Peggy, whose reality, it could be argued, was literally shifting as she faced moving home. First, however, I outline more broadly the context of everyday literacies in the lives of families on the estate, and look more closely at the experience of another participant family: Katie and Colin.

\section{Everyday lives and literacies on the estate: the data}

The research took place on a housing estate built predominantly following the Second World War to house residents bombed out of their inner-city homes and as part of what was known as the 'slum clearance'. Alongside the older part of the estate, dating from the 1930 s and built around crescents, are newer, prefabricated post-war houses originally intended as a short term measure; however, many residents, including one of the families with whom I worked, still reside in these steel-structured dwellings. Narratives of residents who have lived on the estate since it was built suggest a nostalgic sense of hope for the future (Jones et al, 2013). In more recent times, however, as Hanley notes, (2012 p. 146) 'estates have come to mean more as a cipher for a malingering society than as places where people actually live'.

The challenges of economic disadvantage are compounded across many aspects of life in communities such as this, as Wilkinson and Pickett (2010) highlight in their exploration of the impact of material inequality on wellbeing. According to local authority data, and compared to the wider city, quantitative indicators suggest a higher than average number of residents on this particular estate claiming benefits; the number claiming disability living allowance is twice that of the city's average. The estate has a higher than average population of elderly residents living alone and of young mothers. Until its replacement in 2010 by an academy co-sponsored by the local university, a local comprehensive school was ranked amongst the lowest in attainment amongst schools city-wide. Many of these issues are at the centre of welfare provision on the estate.

Literacy has a prominent presence on the agenda of this provision, which includes an action plan delivering literacy awareness training for public workers such as health visitors in order that they 'spot the signs of low level literacy' (local authority documentation). Support includes services which could be aligned with what Wainwright and Marandet (2013) have termed 'supportive power': practices which 'shape subjectivities that fit in with the government's idea of community as a site of empowerment' ( $p$. 519). This includes help with 'form filling' from the local housing authority. There is an emphasis on the role of literacy at home in the form of reading stories, for example, in supporting the attainment of children at school, although in much of the provision, what Hamilton and Tett (2012, p. 45) describe as a discourse of 'human resource development' dominates. Participants described, for example, the computer classes they were obliged to attend as benefit claimants, where the focus was on writing CVs and formatting word-processed letters of application for jobs.

As is highlighted by Taylor (1996) and Eubanks (2012), models of literacy which fail to notice the realities of people's daily engagement with text can lead to structures of support which may in fact compound the challenge for those in need of access to textbased resources. This is evident in what has happened at perhaps the most iconic site of literacy within the community: the local library. The library within this community is well-used, with a committed staff who know their users well and users who have come to see the library as a vital resource, not only for the borrowing of books, but for access to computers, for advice and signposting, and as part of a weekly - and sometimes daily 
- routine where they come in to chat to the staff, emphasising the library's role as a site for social interaction (Pahl and Allan, 2011). Wider economic cuts have in many contexts been left to local professionals to implement, as is noted by Hamilton and Tett (2012). In this context, the library service city-wide has introduced a charge for the use of the computers, as explained by the local library manager: 'The first hour is free and it's a pound an hour after that'. For library users in this community, this means that:

On a Monday, all the terminals are full because that's when you get your free hour and then it tends to tail off again until the end of the week when it picks up again as people realise that they need to do this or do that. Certainly things like benefit and welfare claims because they have to come back to check the reply.

Graham, local library manager

This 'digital dead end' (Eubanks, 2012) demonstrates the impact of austerity politics on the everyday lives of some of the most vulnerable in our society; it is an example of the role of the 'official text' of poverty described by Taylor (1996) in the imbrication of economic and cultural injustice. For the families with whom I worked, literacy was central to their negotiation of economic challenge, as is evident in the home of Katie and Colin.

Katie is thirteen years old and lives with her dad, Colin. Since leaving compulsory schooling, her brother, James, attends a residential college for students with profound and multiple learning difficulties. Colin has raised his two children on his own since the sudden death of his wife nine years ago. His former passion for fishing was one of many things that had to change when he lost his wife and had to stop work because of his caring responsibilities. Colin describes himself as not reading anything apart from his newspaper, and attributes a lack of confidence with reading and writing to having 'messed about too much' at school. He sees Katie, on the other hand, as a prolific reader of print-based text:

You want to see her little bookcase - it's jammed. You go into her bedroom and constantly there will be a book on the bed and on the floor. She loves to read and I'm really pleased about that.

Everyday life for Katie and Colin demonstrates the centrality of shared practice around language and literacy in the negotiation of experience. This includes discussions about Katie's activity on Twitter, her engagement with fan fiction based on contemporary rock bands her father regularly, and playfully, compares to his own favourites as a younger man, and finding recipes in magazines for family meals. Upon losing his wife, the scale of the challenge for Colin was significant given his son's needs. He is honest about the way in which his four year old daughter helped him to cope at the time:

I had to learn what James was saying because he doesn't speak. [...] I'm sitting there thinking, 'what the hell are you talking about?' Because I didn't have a clue. Katie would say 'he wants a cup of tea' and I'm going 'why don't he say that?' She taught me a lot about how to look after him.

Bureaucratic literacies figure highly in day-to-day life because of the nature of the family's circumstances. Father and daughter pool their skills for these, and other tasks:

Colin: I don't really [write] but when I do I get madam to check it for me. [...] Legal documents for [the kids]. When James comes home I have to write for his carer's allowance and I have to stipulate what he's having and why and all this sort of thing. [...] I'll say to Katie, 'I'll write this out but tell me if it's ok [..] and she'll go over it and change things like correct my spelling mistakes and put the punctuation in. 
Katie: We help each other out like that [...] say I'm stuck on a maths problem he'll help me out with that and then, in return, if he's typing a letter or something I'll help with his spelling and stuff.

For this family, working together with the resources of language and literacy is essential to their negotiation of everyday life. It is an example of the resourcefulness often ignored in dominant discourses of deficit, such as that presented during discussion of the current study with a local government worker, who warned me that the literacies I would encounter when working with participants were more likely to be characterised by 'what they haven't got'. A focus on literacy in this context offers an insight into the experiences of those who bear the brunt of social policy, reminding us of the centrality of literacy as a resource in the negotiation of these experiences. The story of Peggy, presented next, demonstrates the impact of a particular social policy on the experience of everyday life. Conceptions of literacy that include the role of material objects in our communicative repertoire reveal the ways in which, for Peggy, literacy is something which not only constricts her life, but is also a resource which can be utilised to construct it.

\section{Peggy}

Peggy is 62. At the start of the project, she had lived for 33 years in the council home in which she'd raised her three children. She has been a widow for nine years, but her family remain close by, including ten grandchildren and a newborn great-granddaughter, her siblings and her mother, whom she visits every week to share caring responsibilities. Peggy worked until recently at a local museum as a costumed interpreter and cleaner. Since being made redundant, Peggy has experienced health issues and has found it difficult to return to work.

Discussing her experiences of reading and writing, Peggy started with school: 'I had a bit of trouble reading and writing'. This experience has influenced her confidence since:

I'm not very confident at writing. I can spell but I seem to get things wrong. My handwriting starts off really nice and neat and then it goes wrong.

The technicist model does not seem to reflect the range of ways in which Peggy uses writing. Although she claims 'I don't do a lot of writing', she lists a range of reasons why she would commit pen to paper as part of her everyday life.

Writing is [...] for all sorts, isn't it? Filling in forms, writing a shopping list, writing birthday cards, writing letters to your friends.

Peggy enjoys puzzles - 'the easy ones' - and the centrality of shared play and oracy is clear in the way in which Peggy makes use of the computer. She does not own her own computer, but makes use of her sister's and mother's when she goes to visit, often logging on to Facebook or playing online games.

When I go to [my sister's] I always ask if I can go on the computer and she says 'it's already on for you, waiting'. 'Cos she knows. [...] Mum goes to bed early, so I say I'll just have half an hour on the computer then go to bed. I end up playing games. I like that bubbles one where you have to shoot them.

During the course of the research, our discussions of everyday reading and writing became focused on one significant event in Peggy's life.

In April, they'll charge you for the two bedrooms that you're not using - it's called a 'bedroom tax' - and I said to [my daughter] "I can't afford to live here". 
Peggy therefore started the process of moving home. This process was one where literacies were prominent from the outset and Peggy's description of the process demonstrates the way in which dominant practices shape the experiences of those in most need of support, evoking the 'toxic literacies' of bureaucracy referred to by Taylor (1996).

Peggy: To move, I'd have to fill in a form for the council and then start bidding. Which would be a problem. You have to either look in the paper or you'd go on the computer but when you haven't got a computer it's a bit awkward.

Usually on Monday they put what's going in the paper and you have to bid and if someone has a higher bid than you, like if they have more need than you, then they get it.

I've filled in the form [...] My daughter did it for me. I've sent it in - or I think I've sent it in anyway - and I've just got to wait for my bidding number and that hasn't come yet.

Peggy is rendered passive by bureaucratic texts that control the application system. This is a particular issue for those who may find it challenging to access either paper-based forms or who do not have access to a computer. The timing of the process is out of the user's control; hence, lives are framed by a weekly round of deadlines. The marketisation of need means that there is a lack of certainty in any application, making waiting time a constant variable. 'I've just got to wait' suggests that this is a system where the person is secondary to the text.

Over the next few months, Peggy described her feelings as she faced the move.

I'm a bit unsure about moving because it's the memories in the house [...] Me and [my husband] and the kids growing up and that. (July 2012)

Leaving this; leaving [my husband]; leaving the memories in the house of bringing the kids up and moving from my friends. (Jan 2013)

An important theme in Peggy's talk over these months was what she was going to do with her possessions as she prepared for the move into a smaller home, which turned out to be a one-bedroomed flat in a warden-assisted housing complex. As the day drew nearer, we talked about the things she was giving away, and those she had chosen to keep. These conversations reflected the role in Peggy's life of 'evocative objects' (Turkell, 2007), and her engagement with what Pahl and Rowsell (2010) have termed 'artifactual literacies'.

I've been very harsh with myself but there are some things I'll never part with even though I ain't got room to put them in.

Within the upheaval of the move, Peggy's evaluation of her possessions demonstrated the way in which she was responding to the situation by using material objects as a way to construct her new home. Miller points out the 'résumé effect' of the home and that

moving house allows for a kind of critical realignment of persons with their possessions. [It] allows people to reconstruct their personal biography as represented in memories of associated objects and thereby the sense the family has of itself [...] people have a chance to work on and repair the way they represent themselves and their own histories to themselves, and to the world, in accordance with how they now want to see themselves (Miller, 2010, p. 97). 
In her organisation of her things, Peggy evokes Brandt and Clinton's view of literacy as 'an abstraction or redistribution of elements of the human lifeworld into the lives of things' (Brandt and Clinton, 2002, p. 345). Observing Peggy over the process of her move led me to reflect on the ways in which, for her, everyday life was becoming literally defined by a sense of movement in response to wider contexts. Peggy agreed to film a video tour of her new home in order to present the ways in which she was undergoing the process of constructing it. Amongst the first things to be the focus of Peggy's tour was a display cabinet, from which she took out a small teddy bear (Fig 1):

This teddy bear here was the last thing my husband ever bought me. He died nine years ago. When I went to see him in hospital, he'd got this teddy bear sticking out his pocket and he says 'I bought it especially for you'. So I keep that on show.

\section{Peggy's video tour of her new home}

The notion of 'show' is significant for Peggy as she negotiates her new role as a single occupant of this space. With her, she has brought objects which hold key memories, and which have been bought by others. She describes her collection of Cliff Richard memorabilia, which 'no-one wanted out' in her previous home. Now, they take pride of place, demonstrating a key 'ruling passion' (Barton and Hamilton, 1998). Peggy's fridge can be read as an example of a text which signifies the way in which she has written herself into her new home (Fig 2). Amongst the array of fridge magnets are ones bought by friends and family from holiday, ones which are mementoes of day trips and events such as going with her sister to see Cliff Richard in concert. There is one which she found in a box during the move, a toy character which was cherished by her daughter some twenty or more years previously. The fridge, along with other objects such as a framed cross-stich made for Peggy by her daughter following the death of her father (Fig 3), illustrate the way in which 'objects mediate our interactions with other places and other times' (Brandt and Clinton, 2002, p. 345), supporting the negotiation of an acutely emotional process.

\section{Noticing how people read and write}

For the families with whom I have worked on this project, everyday life is subject to significant global forces. Current policy discourse does not account for the complex realities of everyday lives and, as such, communities facing economic hardship bear the brunt of injustice. Dominant literacy practices in many ways compound the level of challenge they face, constituting cultural injustice through 'nonrecognition' (Fraser, 1995).

As can be seen in the practices presented here, local responses to such contexts reflect far broader repertoires than are assumed in policy, where, as Taylor notes, too often 'lives are reconstructed, fabricated to fit the dominant ideologies of society'. These experiences demonstrate that 'the realities of lives that are lived are not represented in official texts' (Taylor, 1996, p. 242). In contrast to popular discourses of undeservedness and dysfunctionality, the shared practice of Katie and her father demonstrates a family facing economic and social challenge working together to negotiate their experiences, pooling resources and learning from each other. Official texts have led to significant change for Peggy in recent months, and a bureaucratic process has shaped her experience of a social policy which does not recognise what Douglas (1991, p. 289) has noted, that 'having shelter is not having a home, nor is having a house, nor is home the same as a household'. However, the textual and artifactual assets of her everyday life have allowed Peggy to author herself into her new home.

Recognising the ways in which literacies are utilised as resources in the complex negotiation of everyday life can help us to develop an understanding of the impact upon 
these lives of recent social policy. However, an essential part of a response to a policy context which poses an acute threat to social justice is the recognition of the role that literacy plays not only as a controlling force, but also as 'a resource for people acting back against the forces that limit their lives' (Hamilton, Tett and Crowther, 2012, p. 5). It must be recognised, as Hamilton, Tett and Crowther also note $(2012$, p. 5), that 'the deficit, if there is one to be located, is in a society that excludes, reduces and ridicules the rich means of communication that exist among its people'. This means noticing how people read and write and how this affects their access to resources. It also means noticing the ways in which communicative resources offer powerful means of negotiating everyday life. As those working in the field of literacy, this means we are able to play a part in challenging the economic as well as the cultural injustice faced by communities as a consequence of austerity politics.

\section{References}

Brandt, D. and Clinton, K. (2002) 'Limits of the Local: Expanding Perspectives on Literacy as a Social Practice', Journal of Literacy Research 34, pp. 337-356

Barton, D. and Hamilton, M. (1998) Local Literacies: Reading and Writing in One Community. London: Routledge

Bourdieau, H. (1977) Outline of a Theory of Practice. Cambridge: Cambridge University Press

Brice Heath, S. (1983) Ways with Words. Cambridge: Cambridge University Press

Class (Centre for Labour and Social Studies) (2013) Austerity illusions and debt delusions. http://classonline.org.uk/pubs/item/austerity-illusions-and-debt-delusions last accessed January 13th 2014

Comber, B. (2012) 'Mandated literacy assessment and the reorganisation of teachers' work: federal policy, local effects.' Critical Studies in Education, 53 (2) pp. 119-136.

De Certeau, M. (1984) The Practice of Everyday Life. London: University of California press

Department for Work and Pensions (2013) 'Simplifying the welfare system and making sure work pays', https://www.gov.uk/government/policies/simplifying-the-welfaresystem-and-making-sure-work-pays/supporting-pages/making-sure-housing-support-isfair-and-affordable last accessed January 13th 2014

Douglas, M. (1991) 'The Idea of a Home: A Kind of Space', Social Research 58:1, pp. 287-307

Eubanks, V. (2012) Digital Dead End: Fighting for social justice in the information age. Cambridge MA: MIT Press

Fraser, N. (1995) 'From redistribution to recognition? Dilemmas of justice in a postsocialist age' New Left Review I/ 212, pp. 68-93

Haddad, M. (2012) The Perfect Storm: Economic stagnation, the rising cost of living, public spending cuts, and the impact of UK poverty. Oxford: Oxfam GB

Hall, C. and Thomson, P., 2010. 'Grounded literacies: the power of listening to, telling and performing community stories' Literacy. 44(2) pp. 69-75 
Hamilton, M. (2012) Literacy and the Politics of Representation. Oxon: Routledge.

Hamilton, M. and Tett, L. (2012) 'More powerful literacies: The policy context', in Tett, L. Hamilton, M. and Crowther, J. (eds) More Powerful Literacies. Leicester: NIACE, pp. 3158

Hamilton, M., Tett, L. and Crowther, J. (2012) 'More powerful literacies: An introduction' in Tett, L. Hamilton, M. and Crowther, J. (eds) More Powerful Literacies. Leicester:

NIACE, pp. 1-12

Hanley, L. (2012) Estates: An intimate history (new edition). London: Granta

Hansard (2013)

http://www.publications.parliament.uk/pa/cm201314/cmhansrd/cm130626/debtext/130 626-0001.htm\#13062665000002 last accessed January $13^{\text {th }} 2014$

Jones, S., Hall. C, Thomson, .P, Barrett, A. \& Hanby, J. (2013): Representing the 'forgotten estate': participatory theatre, place and community identity, Discourse: Studies in the Cultural Politics of Education 34 (1) pp. 118-131

Miller, D. (2010) Stuff. Cambridge: Polity Press

Pahl, K. and Allan C. (2011) 'I don't know what literacy is: Uncovering hidden literacies in a community library using ecological and participatory methodologies with children.' Journal of Early Childhood Literacy. Vol 11, No 2, pp. 190-213

Pahl, K. and Rowsell, J. (2010) Artifactual Literacies: Every object tells a story. New York: Teachers College Press

Pink, S (2007) 'Walking with Video', Visual Studies, 22 (3) pp.240-252

Pink, S. (2012) Situating Everyday Life London: Sage

Sennett, R. (2003) Respect: The formation of character in an age of inequality. London Allen Lane

Street, B. (1984) Literacy in Theory and Practice. Cambridge: Cambridge University Press

Taylor, D. (1996) Toxic Literacies: Exposing the injustice of bureaucratic texts.

Portsmouth, NH: Heinemann

Turkle, S. (ed) (2007) Evocative objects: things we think with. Cambridge, MA: The MIT Press

Wainwright, E. and Marandet, E. (2013) 'Family learning and the socio-spatial practice of 'supportive' power, British Journal of Sociology of Education, 34:4, pp.504-524

Wilkinson, R. and Pickett, K. (2010) The Spirit Level: Why Equality is Better for Everyone. London: Penguin 
'How people read and write and they don't even notice': Everyday lives and literacies on a Midlands council estate 